\title{
A putative OTU domain-containing protein 1 deubiquitinating enzyme is differentially expressed in thyroid cancer and identifies less-aggressive tumours
}

\begin{abstract}
A P Carneiro ${ }^{1}$, C F Reis ${ }^{1}$, E C Morari ${ }^{1}$, Y C P Maia ${ }^{2}$, R Nascimento ${ }^{2}$, J M C Bonatto ${ }^{3}$, M A de Souza ${ }^{4}$, L R Goulart ${ }^{\star}, 2,5$ and L S Ward ${ }^{*, 1}$

${ }^{1}$ Laboratory of Cancer Molecular Genetics, Faculty of Medical Sciences (FCM), University of Campinas (Unicamp), Campinas, SP, Brazil; ${ }^{2}$ Laboratory of Nanobiotechnology, Institute of Genetics and Biochemistry (Ingeb), Federal University of Uberlandia, Uberlandia, MG, Brazil; ${ }^{3}$ Department of Biochemistry, Chemistry Institute, University of São Paulo, São Paulo, Brazil; ${ }^{4}$ Laboratory of Molecular Biology, Federal University of Uberlandia, Institute of Biomedical Sciences, Uberlandia, MG, Brazil and ${ }^{5}$ Department of Medical Microbiology and Immunology, University of California-Davis, Davis, CA, USA
\end{abstract}

Background: This study aimed to identify novel biomarkers for thyroid carcinoma diagnosis and prognosis.

Methods: We have constructed a human single-chain variable fragment (scFv) antibody library that was selected against tumour thyroid cells using the BRASIL method (biopanning and rapid analysis of selective interactive ligands) and phage display technology.

Results: One highly reactive clone, scFv-C1, with specific binding to papillary thyroid tumour proteins was confirmed by ELISA, which was further tested against a tissue microarray that comprised of 229 thyroid tissues, including: 110 carcinomas (38 papillary thyroid carcinomas (PTCs), 42 follicular carcinomas, 30 follicular variants of PTC), 18 normal thyroid tissues, 49 nodular goitres (NG) and 52 follicular adenomas. The scFv-C1 was able to distinguish carcinomas from benign lesions $(P=0.0001)$ and reacted preferentially against T1 and T2 tumour stages $(P=0.0108)$. We have further identified an OTU domain-containing protein 1 , DUBA-7 deubiquitinating enzyme as the scFv-binding antigen using two-dimensional polyacrylamide gel electrophoresis and mass spectrometry.

Conclusions: The strategy of screening and identifying a cell-surface-binding antibody against thyroid tissues was highly effective and resulted in a useful biomarker that recognises malignancy among thyroid nodules and may help identify lower-risk cases that can benefit from less-aggressive management.

The rapid development and widespread use of sensitive imaging techniques, such as the ultrasonography, has resulted in increased frequency of clinically silent lesions that are submitted to diagnostic aspirative citology (Guth et al, 2009).

A parallel increase in the number of patients diagnosed with papillary thyroid carcinomas (PTCs) has been registered almost all over the world (Kilfoy et al, 2009). Nevertheless, mortality rates have remained stable (Davies and Welch, 2010), suggesting that part of these lesions would possibly never evolve to clinically significant cancers. In fact, there is increasing evidence indicating that some immunologic features of the tumour and/or its host may restrain the thyroid cancer development in some individuals 
(Cunha et al, 2012a,b). Conversely, a considerable number of citologycal analyses resulted as indeterminate, leading up to onethird of patients with thyroid nodules to surgeries that were later proven unecesssary, as final histology demonstrated benignancy in $70-80 \%$ of the indeterminate citologies (Piana et al, 2011). This troubling scenario urges the immediate search for reliable diagnostic markers.

Monoclonal antibodies have been used for antigen detection and therapeutics, and their specificity combined with low toxicity make them a promising pharmaceutical commodity. In fact, after vaccines, they comprise the second-largest category of biological medicines in clinical development (Berger et al, 2002). Successful examples include rituximab, approved by the FDA since 1997, an anti-CD20 chimeric antibody that became an integral component of many treatment strategies for non-Hodgkin's lymphoma (Seymour, 2004), and OKT3, an anti-CD3 that is used to reduce graft rejection (Cosimi et al, 1981).

In the present investigation, we have used the combinatorial single-chain variable fragment ( $\mathrm{scFv}$ ) antibody library displayed on a filamentous phage capsid to select and identify tumour-specific antigens in thyroid carcinoma cell surfaces. A highly reactive marker was able to distinguish thyroid malignancies, and may also be useful to identify lower-risk cases.

\section{MATERIALS AND METHODS}

The Research Ethics Committees from University of Campinas (Unicamp), Federal University of Uberlandia (UFU), and Fundação Antônio Prudente (Hospital A. C. Camargo) approved this study under the protocol numbers 096/2008, 026/2009 and $1259 / 2009$, respectively, and a written informed consent was obtained from all patients.

Cell cultures and patients. We used a PTC cell line, NPA, kindly provided by Professor JM Cerutti, from the Federal University of São Paulo, and we also developed a goitre primary human cell culture using fresh thyroid tissue obtained from a patient submitted to surgical removal of a multinodular goitre at the Surgery Center of the UFU Hospital.

Two hundred and twenty-nine thyroid cases consecutively examined at the Hospital A. C. Camargo were assembled into a tissue microarray (TMA) that included 110 samples of welldifferentiated thyroid carcinomas (38 classic forms of papillary thyroid cancer; 30 follicular variants of papillary thyroid cancers and 42 follicular thyroid cancers); 52 follicular adenomas; 49 nodular goitres and 18 normal thyroid tissues. Aggressiveness at diagnosis was ascertained using the American Joint Committee on Cancer/International Union against Cancer staging system, which is based on the tumour size, extrathyroidal invasion, lymph node and distant metastases (TNM), and age; and risk stratification according to the Brazilian updated consensus on thyroid nodules and differentiated thyroid cancer (Rosario et al, 2013). Using these parameters, the patients were grouped into lower-risk (including very low- and low-risk patients) and higher-risk (intermediate and high risk) cases. Patients were followed with periodic whole-body scans, serum TSH and thyroglobulin (Tg) measurements, according to a standard protocol that included X-ray, ultrasonography, computed tomography scan and other eventual procedures to detect distant metastasis for a period of 12-298 months (43.50 \pm 33.29 months) (Rosario et al, 2013). Patients presenting high nonstimulated serum Tg levels $\left(>1 \mathrm{ng} \mathrm{dl}^{-1}\right)$ were submitted to image evaluation. We defined tumours as persistent/recurrent and/or presenting long-distance metastasis, according to the aforementioned parameters.

Construction of human scFv phage library. A scFv antibody library was constructed from total RNA samples obtained from leukocyte cells (peripheral blood) of 25 patients with welldifferentiated thyroid carcinoma. RNA was extracted with TRIzol reagent and then they were mixed together. After that, $20 \mu \mathrm{g}$ of the mixture were submitted to cDNA synthesis with the Superscript III kit (Invitrogen, Carlsbad, CA, USA), following the manufacturer's instructions. Afterwards, heavy- and light-chain variable regions $\left(\mathrm{V}_{\mathrm{H}}\right.$ and $\mathrm{V}_{\mathrm{L}}$ ) were separately amplified by PCR using primers described elsewhere (Marks et al, 1991). All primers used in this study are listed in Supplementary Table 1.

Amplification reactions consisted of $10 \mu \mathrm{l} 10 \times$ PCR buffer, $60 \mathrm{pmol}$ of each primer, $0.25 \mathrm{U}$ of Taq enzyme, $5.0 \mu \mathrm{l} \mathrm{MgCl}_{2}$ $(50 \mathrm{~mm}), 10 \mu \mathrm{l}$ deoxyribonucleotide $\operatorname{mix}(2 \mathrm{~mm}), 10 \mu \mathrm{l} \mathrm{cDNA}$ product and water to reach a final volume of $100 \mu \mathrm{l}$. PCR conditions were: $94^{\circ} \mathrm{C}$ for $5 \mathrm{~min}, 37$ cycles of $94^{\circ} \mathrm{C}$ for $1 \mathrm{~min}, 57^{\circ} \mathrm{C}$ for $1 \mathrm{~min}$ and $72^{\circ} \mathrm{C}$ for $1.5 \mathrm{~min}$. The amplified $\mathrm{V}_{\mathrm{H}}$ and $\mathrm{V}_{\mathrm{L}}$ segments were purified from the agarose gel after electrophoresis, pooled and linked through a series of overlap PCR steps to give the final $s c F v$ products in $\mathrm{V}_{\mathrm{L}}$-linker- $\mathrm{V}_{\mathrm{H}}$ format, with GGSSRSS linker (Andris-Widhopf et al, 2011).

The overlapping PCR reaction consisted of 37 cycles of $94{ }^{\circ} \mathrm{C}$ for $5 \mathrm{~min}, 94^{\circ} \mathrm{C}$ for $1 \mathrm{~min}, 57^{\circ} \mathrm{C}$ for $1 \mathrm{~min}$ and $72^{\circ} \mathrm{C}$ for $1.5 \mathrm{~min}$, followed by a final extension at $72{ }^{\circ} \mathrm{C}$ for $10 \mathrm{~min}$. The scFv gene products were purified and ligated into the display vector pComb3X, both digested with SfiI restriction enzyme, followed by electroporation into XL1-Blue (Stratagene, La Jolla, CA, USA) electrocompetent cells. Colonies were grown on agar plates with $100 \mu \mathrm{g} \mathrm{ml}^{-1}$ carbenicillin and $40 \mathrm{~mm}$ glucose. Afterwards, the colonies were counted to determine the library size, as described elsewhere (Andris-Widhopf et al, 2000). The scFv antibody fragments displayed on the surface of the filamentous phage was performed by rescuing with VCS-M13 helper phage (Stratagene), as previously described (Rader and Barbas, 1997).

DNA sequencing analysis. Single-strand DNA was isolated, and the heavy- and light-chain variable region genes were sequenced using MegaBACE 1000 automatic sequencer (Molecular Dynamics, Sunnyvale, CA, USA). The sequencing reaction was carried out using the DyEnamic ET Dye Terminator Cycle Sequencing Kit (GE Healthcare, USA), following the manufacturer's instructions. The nucleotide sequence of the $\mathrm{V}_{\mathrm{H}}$ and $\mathrm{V}_{\mathrm{L}}$ was determined using MMB4 (5'-GCTTCCGGCTCGTATGTTGTGT-3') and MMB5 $\left(5^{\prime}\right.$-CGTTTGCCATCTTTTCATAATC- $\left.3^{\prime}\right)$ oligonucleotides, and immunoglobulin variable domain sequences and $V$ gene families were analysed using the Ig-BLAST program at NCBI (http:// www.ncbi.nlm.nih.gov) and VBASE2 (http://www.vbase2.org) (Retter et al, 2005).

Selection of scFv library on cells. Three selection cycles were performed using the phage display technology and the BRASIL method (biopanning and rapid analysis of selective interactive ligands) (Giordano et al, 2001) to verify phage binding to intact cells. Briefly, the phage displayed scFv library was positively selected by biopanning on PTC cell line (NPA) after a previous negative selection against goitre primary human cell culture (benign disease) to eliminate major cross-reactivities. Cells were

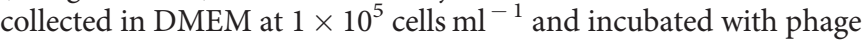
in $1.5-\mathrm{ml}$ microtubes for $1 \mathrm{~h}$ on ice. Subsequently, $100 \mu \mathrm{l}$ of the cellphage suspension was transferred to a new tube containing $200 \mu \mathrm{l}$ of dibutyl:phthalate:cyclohexane $(9: 1 ; \mathrm{v}-\mathrm{v})$ and centrifuged at $10000 \mathrm{~g}$ for $10 \mathrm{~min}$ at $25^{\circ} \mathrm{C}$. Alternatively, in the steps of negative selection when phages were incubated with the strain of benign thyroid cells after centrifugation, phages were collected above the liquid phase from the organic layer and these phages were incubated for an additional $1.5 \mathrm{~h}$ with tumour cells on ice. Finally, the tube was frozen in liquid nitrogen, the bottom of the tube sliced off and the cell-phage pellet transferred to a tube containing $50 \mathrm{ml}$ culture of E. coli XL1-Blue in log phase and incubated for $15 \mathrm{~min}$ at room temperature to phage recovery. 
Expression of soluble scFvs in $\boldsymbol{E}$. coli. After the third round selection, plasmidial DNA from XL1-Blue cells was extracted and used to transform electrocompetent non-suppressor TOP10 cells (One ShotTOP10 Electrocomp E. coli, Invitrogen) for soluble expression of scFv molecules. Ninety-six random clones were chosen from plates and inoculated into a 2-ml deep-well plate (NUNC, Roskilde, Germany) in $1 \mathrm{ml}$ of super broth (SB) medium containing $100 \mu \mathrm{g} \mathrm{ml}^{-1}$ carbenicillin and $40 \mathrm{~mm}$ glucose, then followed by incubation for $14 \mathrm{~h}$ at $37^{\circ} \mathrm{C}$ and shaken at 300 r.p.m. After amplification, $10 \mu \mathrm{l}$ of cells were transferred to a new deepwell plate containing the same medium and incubated for $4 \mathrm{~h}$ at $37^{\circ} \mathrm{C}$ and 300 r.p.m., afterwards followed by centrifugation at $3000 \mathrm{~g}$ for $10 \mathrm{~min}$. The supernatants were substituted by $1 \mathrm{ml}$ of SB medium containing $100 \mu \mathrm{g} \mathrm{ml}^{-1}$ carbenicillin and $2.5 \mathrm{~mm}$ of isopropyl- $\beta$-D-thiogalactoside (IPTG, Sigma, St Louis, MO, USA); after that, the scFv induction was carried out for $18 \mathrm{~h}$ at $30^{\circ} \mathrm{C}$ and 300 r.p.m. The supernatant containing the $\mathrm{scFv}$ was obtained by $3000 \mathrm{~g}$ centrifugation for $20 \mathrm{~min}$ and was directly subjected to dotblot immunoassay and purification.

Soluble scFv antibody production and purification. The $\mathrm{scFv}$ clones were transformed in TOP10 E. coli non-suppressor strain and then used to inoculate SB medium containing $50 \mu \mathrm{g} \mathrm{ml}^{-1}$ of carbenicillin and $2 \%$ glucose. The culture was grown under agitation (250 r.p.m.) overnight at $37^{\circ} \mathrm{C}$ and $2 \mathrm{ml}$ were diluted in $200 \mathrm{ml}$ of supplemented SB medium. The culture was incubated under agitation for $6-8 \mathrm{~h}$ at $37^{\circ} \mathrm{C}\left(\mathrm{OD}_{600}=1.0\right)$, and centrifuged at $3000 \mathrm{~g}$ for $10 \mathrm{~min}$ at $4{ }^{\circ} \mathrm{C}$. Bacteria were resuspended in $200 \mathrm{ml}$ supplemented carbenicillin SB medium and induced by 2 mM IPTG at $30{ }^{\circ} \mathrm{C}$ overnight. Supernatant containing antibody was obtained after centrifugation at $5000 \mathrm{~g}, 4^{\circ} \mathrm{C}, 15 \mathrm{~min}$, after that, His-tagged $\mathrm{scFv}$ fragments were purified by immobilized-metal (Ni) affinity chromatography (HisTrap HP, GE Healthcare) by high-performance liquid chromatography (HPLC, Amersham Biosciences, Sunnyvale, CA, USA) according to the manufacturer's instructions. All eluted fractions were identified for the presence of antibody fragments by dot-blot immunoassay, positive fractions were pooled, desalted by a Centriprep column (Millipore, Billerica, MA, USA), lyophilised, resuspended in PBS and then measured at $280 \mathrm{~nm}$ for protein. The purity and correct size of $\mathrm{scFv}$ was verified on $12 \%$ SDS-PAGE gel followed by silver staining (ProteoSilver Plus Silver Stain Kit, Sigma).

ELISA screening. Maxisorp 96-well (NUNC) plates were coated with $1.0 \mu \mathrm{g}$ per well of total pooled protein extracted from goitre, adenoma and tumour thyroid tissues to screen for clones that could differentially recognise thyroid cancer antigens in $100 \mu \mathrm{l}$ of sodium bicarbonate buffer ( $\mathrm{pH} 7.4$ ) overnight at $4{ }^{\circ} \mathrm{C}$. Wells were washed three times with PBST and then blocked for $1 \mathrm{~h}$ at $37^{\circ} \mathrm{C}$ with PBS plus 5\% nonfat milk (PBSM 5\%). After blocking, wells were washed three times with PBST and $4 \mu \mathrm{g}$ of purified scFvs were added to each well and incubated for $2 \mathrm{~h}$ at room temperature under low agitation. Then, the plate was washed three times with PBST, followed by incubation with HRP-conjugated rat anti-HA (Roche Applied Science, Indianapolis, IN, USA) diluted (1:1000) in PBSM 5\% for $1 \mathrm{~h}$ at $37^{\circ} \mathrm{C}$. After another four washes, the chromogenic substrate OPD SigmaFast (Sigma-Aldrich) was added and the absorbance was measured at $492 \mathrm{~nm}$.

Tissue microarray (TMA) construction and immunohistochemistry. The affinity of the monoclonal scFv antibody was verified by immunohistochemistry on the TMA. Paraffinembedded tissue sections from 229 patients were deparaffinized, rehydrated and incubated three times with $3 \% \mathrm{H}_{2} \mathrm{O}_{2}$ for $5 \mathrm{~min}$. The tissue sections were rinsed in distilled water, and then submitted to heat pretreatment in $0.1 \mathrm{M}$ sodium citrate buffer for $35 \mathrm{~min}$ at $95^{\circ} \mathrm{C}$ for antigen retrieval. The sections were rinsed again and then blocked for $1 \mathrm{~h}$ in PBS-10\% BSA. Then, $4 \mu \mathrm{g} \mu \mathrm{l}^{-1}$ of the scFvs diluted in Novocastra IHC Diluent (ref. RE7133, Leica Biosystems, Newcastle, United Kingdom) were applied and incubated for $14 \mathrm{~h}$ at $4{ }^{\circ} \mathrm{C}$ overnight. After that, slides were rinsed four times, $5 \mathrm{~min}$ each, with PBS. Subsequently, they were incubated with HRPconjugated rat anti-HA (Roche Applied Science) diluted $(1: 200)$ in buffer for $1 \mathrm{~h}$ at room temperature, rinsed with PBS and then incubated with Advance HRP Enzyme Dako (San Juan Capistrano, CA, USA) for $30 \mathrm{~min}$ at $37^{\circ} \mathrm{C}$. The bound antibody was detected with the DAB substrate (Sigma) and counterstained with haematoxylin. Analyses of staining were carried out using the Automated Cellular Imaging System ACIS-III (Chroma Vision Medical Systems Inc, Dako) for IHC quantification.

Briefly, each tissue spot was digitalised to the system software, and a computer algorithm based on the intensity and extension of the brown staining attributed numerical values to each spot. A final score, given by the mean of triplicates, was used for statistical comparisons.

Protein sequencing by LC-MS/MS and target identification. Proteins in PTC and goitre tissues were resolved by twodimensional gel electrophoresis (2D) (Roessler et al, 2006). Two gels were performed for both the papillary carcinoma and goitre proteins. One was stained with Comassie Brilliant Blue G-250 dye (Bio-Rad, Hercules, CA, USA) and the other was transferred onto a nitrocellulose membrane (GE) for western blot with scFV-C1 antibody, using the HRP-conjugated rat anti-HA (Roche Applied Science). The corresponding spots that $\mathrm{scFv}$ antibody recognised in the western blot were excised from the gels and subjected to trypsin digestion (Wilm et al, 1996), followed by liquid chromatography mass spectrometry (LC-MS/MS) to allow identification.

Peptides were identified by on-line chromatography using a Cap-LC coupled to a Q-TOF Ultima API mass spectrometer (Waters, Milford, MA, USA). The resulting fragmented spectra were processed using the ProteinLynx 4.0 software (Waters), and
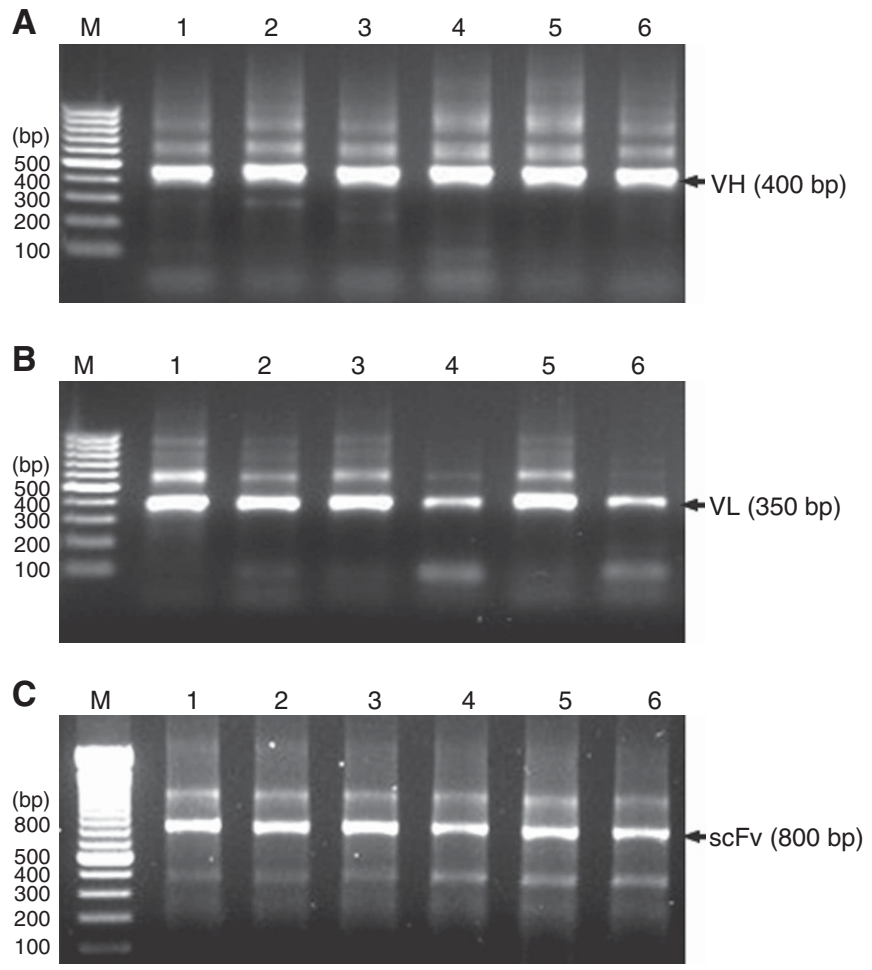

Figure 1. Phage scFv library antibody construction. The amplified gene fragments for the variable regions of the heavy- $\left(V_{H}\right)(A)$ and lightchain $\left(V_{L}\right)(B)$ gene repertoires corresponded to the expected sizes of $\sim 400$ and $\sim 350 \mathrm{bp}$, respectively. The resulting $V_{H}$ and $V_{L}$ fragments were assembled into scFv inserts by overlapping PCR (C). 
we used the MASCOT MS/MS Ion Search system to blast the sequences against the SwissProt and NCBInr databases. According to the MASCOT probability method, only significant $(P<0.05)$ hits were accepted.

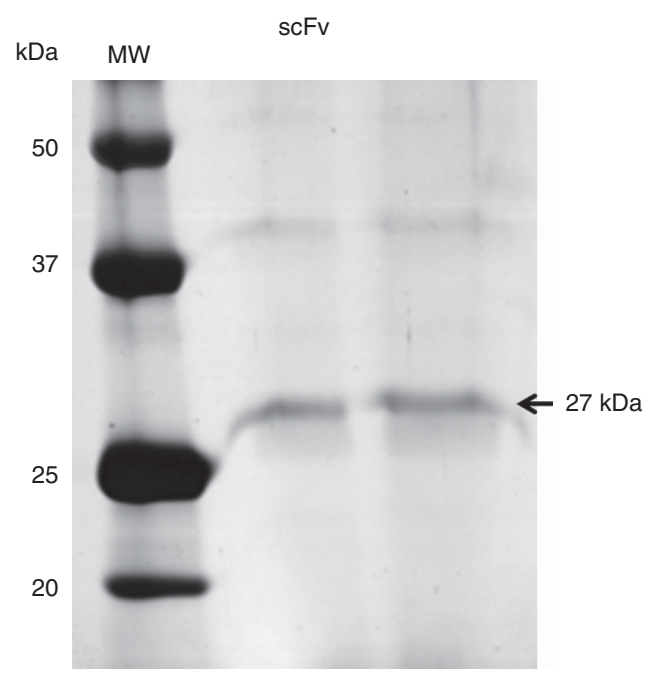

Figure 2. Evaluation of scFv purification after IPTG induction. Soluble scFv antibody was produced by induction of scFv phagemid pComb3X in E. coli TOP10 cells. His-tagged scFv fragments were purified by immobilized-metal (Ni) affinity chromatography and subjected to $12 \%$ SDS-PAGE. The gel was silver stained using ProteoSilver. A band of the expected size for scFv is $27 \mathrm{kDa}$. MW, protein marker.
Statistical analysis. We employed GraphPrism 5.0 software (GraphPad Software Inc., San Diego, CA, USA) to analyse the differences of scFv-C1-positive staining in pathological groups. We have used sensitivity, specificity, positive-predictive value and negative-predictive parameters in the Fisher's test. For ACIS imaging values, the Mann-Whitney test (nonparametric analyses) was applied to determine staining intensity differences between disease groups in the TMA. A value of $P<0.05$ was considered statistically significant.

\section{RESULTS}

Phage library construction and characterisation. The amplified gene fragments for the variable regions of the heavy- $\left(\mathrm{V}_{\mathrm{H}}\right)$ and light-chain $\left(\mathrm{V}_{\mathrm{L}}\right)$ gene repertoire corresponded to the expected sizes of $\sim 400$ and $\sim 350 \mathrm{bp}$, respectively (Figure $1 \mathrm{~A}$ and $\mathrm{B}$ ). The resulting $\mathrm{V}_{\mathrm{H}}$ and $\mathrm{V}_{\mathrm{L}}$ fragments were assembled into $\mathrm{scFV}$ inserts by overlapped PCR reactions, allowing the random association of heavy and light chains to maximise combinatorial reassortment, as demonstrated in Figure 1C. The resulting library size was $1.02 \times 10^{6}$ clones. Aiming to assess the diversity of scFvs, 48 clones were randomly selected and their DNA sequenced. The variable regions were derived from nine different $V$ gene families, including three $\mathrm{V}_{\mathrm{H}}$ gene families $\left(\mathrm{V}_{\mathrm{H}} 1,3\right.$ and 4$)$ and six $\mathrm{V}_{\mathrm{L}}$ subgroups ( $\mathrm{V} \kappa 1,2$ and 3 and $\mathrm{V} \lambda$ 1, 2, 4, 5 and 6), demonstrating that the $s c F v$ gene fragments were distributed across the full repertoire of antibody germline genes.

The final product containing purified $\mathrm{scFv}$ was subjected to SDSPAGE to identify the purity and molecular mass, as shown in Figure 2. The purified scFv exhibited the protein band size of $27 \mathrm{kDa}$.

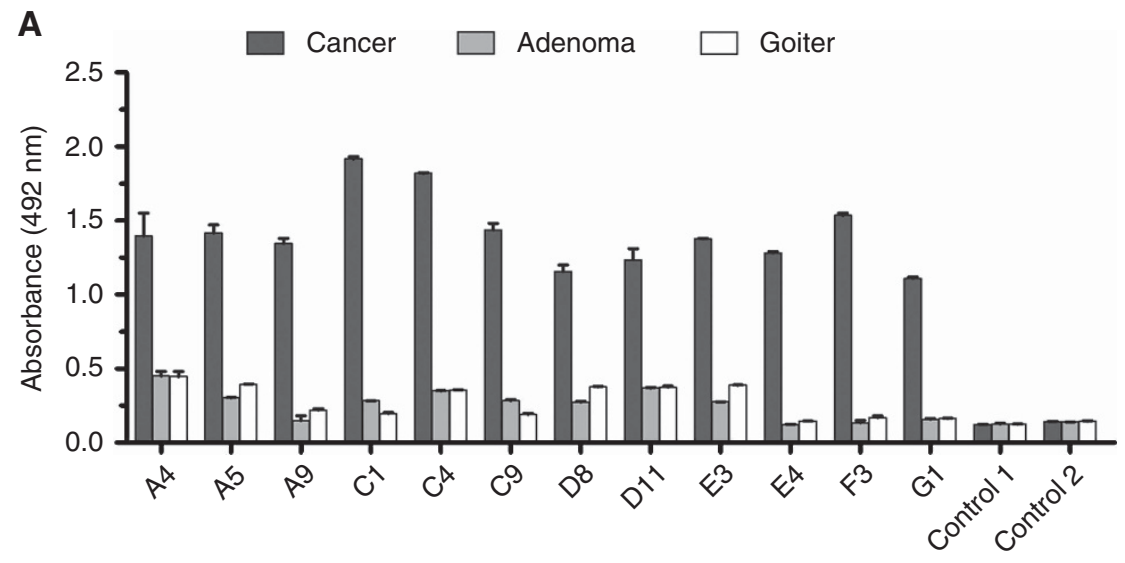

Selected scFv clones

B

scFvC1 clone
Ab family

VL IGLV3-21*03

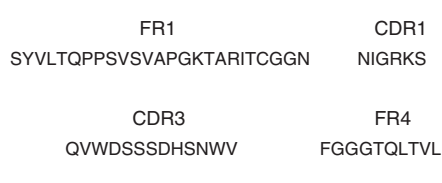

FR

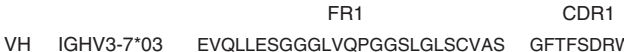

FR2 CDR2 FR3

VHWYQQKPGQAPVLVVY DDS DRPSGIPERFSGSNSGNTATLTISRVEAGDEADYYC

$\begin{array}{cc}\text { CDR3 } & \text { FR4 } \\ \text { VRGAGWLLDH } & \text { WGQGILVTVSS }\end{array}$

FR2 CDR2 FR3

MSWVRQAPGKGLEWVAK IKQDGSEK LYVDSVKGRFTIPRDNSKNSLYLQMDSLRAEDTAVYYC

Figure 3. ELISA screening of antibody fragments (scFv). The scFv clones were subjected against a total protein extracted from papillary thyroid cancer (black), follicular adenoma (gray) and goitre (white) tissues. All clones showed better reaction with cancer proteins. No positive signal was observed in the negative control 1 (scFv specific to Mycobacterium tuberculosis) and control 2 (pComb3X without insert) scFv-C1 clone was selected for additional procedures (A). The amino-acid sequence of scFv-C1 clone with appropriate regions for framework and CDR residues, variable light-chain $\left(V_{L}\right)$ and the variable heavy-chain $\left(V_{H}\right)$ domains $(B)$. 
Dot-blot, ELISA immunoassays validation and DNA sequencing. In the last round of the screening process, clones were grown in 96 deep-well plates, and soluble expressions of scFv fragments were induced and verified by dot blot. scFv clones with high expression were purified by HPLC, and the specificity of these scFvs against thyroid cancer proteins was determined by ELISA screening. Twelve clones demonstrated reactivity to thyroid proteins, presenting low reactivity to goitre and adenoma proteins, as demonstrated in Figure 3A. Among these clones, the clone named $\mathrm{scFv}-\mathrm{Cl}$ was selected based on its reactivity to proceed with validation tests. No positive signal was observed in the negative controls (irrelevant scFv, specific to Mycobacterium tuberculosis and pComb3X without insert).

The complete nucleotide sequence and predicted amino-acid sequence of the heavy- and light-chain variable region of scFv-C1 clone is shown in Figure 3B, and complete sequencing analysis in Supplementary File 2.

Immunohistochemistry. The $\mathrm{scFv}$ monoclonal antibody immunoreactivity was tested on the 229 thyroid samples included in the TMA. Positive staining was observed in PTC, follicular variant of papillary and follicular carcinoma, as demonstrated in Figure 4 panels A, B and C, respectively. Lower positivity was observed among follicular adenomas (28.8\%) and goitres (6.1\%), whereas all normal thyroids tissues were negative (Figure 4D). No labelling was detected in adjacent normal cells, negative control, scFv with specificity for Mycobacterium tuberculosis, and control tissues without $\mathrm{scFv}-\mathrm{C} 1$, secondary $\mathrm{Ab}$ alone (Figure $4 \mathrm{E}$ and $\mathrm{F}$ ).

The staining area was larger in carcinomas than in controls. The $\mathrm{scFv}-\mathrm{C} 1$ antibody distinguished thyroid carcinomas from goitres and normal thyroid tissues, as demonstrated in Figure 4G; Table 1. However, this scFv antibody did not differentiate papillary, follicular and follicular variant papillary carcinoma cases. $\mathrm{scFv}-\mathrm{C} 1$ was able to differentiate lower-risk from higher-risk $(P=0.0108)$ patients. Also, the ACIS imunostaining score was higher in the lower-risk group, as shown in Figure $4 \mathrm{H}$; Table 2.

Identification of OTUD1 deubiquitinating enzyme in thyroid cancer. The $2 \mathrm{D}$ gel electrophoresis method was performed to separate the proteins extracted from a pool of the PTC cases and the goitres. Figure 5 shows the representative proteomic profile for pappilary thyroid carcinoma, in pannel $\mathrm{A}$, in comparison with goitre tissues in panel B. Figure 5 represents the results obtained by the incubation of scFv-C1 antibody with thyroid carcinoma, in panel $\mathrm{C}$, and with goitre in panel $\mathrm{D}$. The scFv antibody recognised two spots; spot 1 was specifically detected in cancer, whereas spot 2 was commonly detected in both cancer and goitre. Spot 1 was further identified as the OTU domain-containing protein 1, a deubiquitinating enzyme, and the spot 2 was identified as haemoglobin subunit alpha, explaining the cross-reactivity with the secondary antibody. The theoretical molecular mass/pI value for OTU1-domain was $51.063 \mathrm{kDa} / 5.68$, fitting well with the
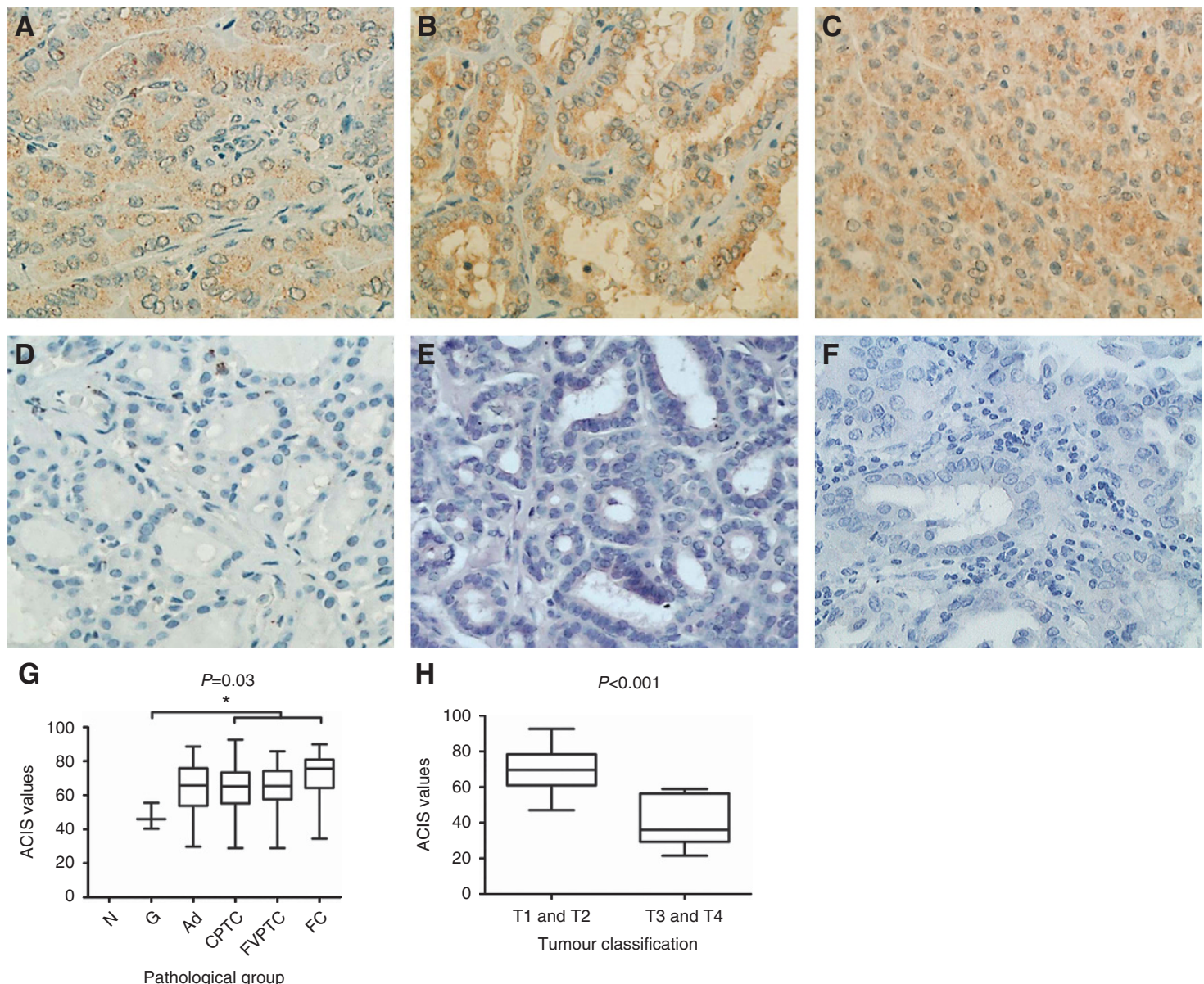

H

$P<0.001$

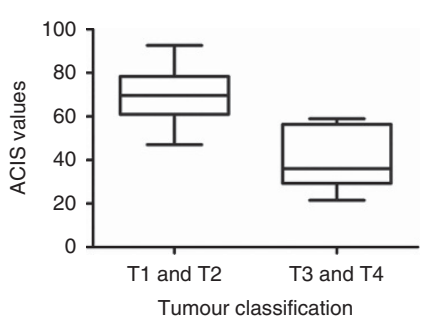

Figure 4. Immunohistochemistry with the scFv-C1 antibody in thyroid tissue. Immunostaining of the scFv-C1 antibody demonstrates reaction in thyroid tumour cells: (A) papillary thyroid carcinoma, (B) follicular variant of papillary thyroid carcinoma and (C) follicular carcinoma. Negative staining was observed in (D) normal thyroid, (E) papillary thyroid carcinoma with irrelevant scFv-C1, specific to Mycobacterium tuberculosis and (F) papillary carcinoma without scFv-secondary Ab alone $(\times 400)$. The graphics show the average of the staining area for each pathological group (G) (normal (N), goitre (G), adenoma (Ad), papillary thyroid carcinoma (CPTC), follicular variant of papillary thyroid carcinoma (FVPTC) and follicular carcinoma (FC)), (H) ACIS immunostaining score low risk vs high risk. Significance was determined by the nonparametric, Mann-Whitney test. 
Table 1. Diagnostic value of scFv-C1 discriminating different histopathological subtypes

\begin{tabular}{|c|c|c|c|c|c|}
\hline Variable & $P^{*}$ & Sensitivity (\%) & Specificity (\%) & PPV (\%) & NPV (\%) \\
\hline $\mathrm{CPTC}+\mathrm{FVPTC}+\mathrm{FC} \times$ benign & $<0.0001^{*}$ & 55 & 82 & 77 & 62 \\
\hline CPTC + FVPTC + FC $\times$ goitre & $<0.0001^{\star}$ & 55 & 94 & 95 & 95 \\
\hline CPTC $\times$ goitre & $<0.0001^{*}$ & 53 & 94 & 87 & 72 \\
\hline FVPTC $\times$ goitre & $<0.0001^{*}$ & 50 & 94 & 83 & 75 \\
\hline $\mathrm{FC} \times$ goitre & $<0.0001^{\star}$ & 60 & 94 & 89 & 73 \\
\hline CPTC + FVPTC + FC $\times$ adenoma & $0.0024^{*}$ & 29 & 45 & 20 & 57 \\
\hline CPTC $\times$ adenoma & $0.0291^{*}$ & 29 & 47 & 43 & 33 \\
\hline FVPTC $\times$ adenoma & 0.0624 & 50 & 71 & 50 & 71 \\
\hline $\mathrm{FC} \times$ adenoma & $0.0035^{\star}$ & 29 & 40 & 38 & 31 \\
\hline CPVF $\times$ FVPTC & 1000 & 53 & 50 & 57 & 45 \\
\hline $\mathrm{CPVF} \times \mathrm{CF}$ & 0.6526 & 53 & 40 & 44 & 44 \\
\hline \multicolumn{6}{|l|}{ CPTC + FVPTC + FC } \\
\hline Low risk $\times$ high risk & $0.0108^{*}$ & 66 & 64 & 78 & 50 \\
\hline
\end{tabular}

Table 2. Carcinoma type, T category and score immunostaining

\begin{tabular}{|c|c|c|}
\hline TNM & $\mathrm{P} / \mathrm{N}$ & Score \\
\hline \multicolumn{3}{|c|}{ Papillary carcinoma } \\
\hline 1 & $14 / 18$ & 85.42 \\
\hline 2 & $3 / 4$ & 78.01 \\
\hline 3 & $2 / 7$ & 35.72 \\
\hline 4 & $1 / 4$ & 30.89 \\
\hline \multicolumn{3}{|c|}{ Follicular variant papillary carcinoma } \\
\hline 1 & $7 / 10$ & 75.27 \\
\hline 2 & $5 / 9$ & 79.09 \\
\hline 3 & $1 / 3$ & 40.31 \\
\hline 4 & $2 / 6$ & 37.90 \\
\hline
\end{tabular}

Follicular carcinoma

\begin{tabular}{|l|l|l|}
\hline 1 & $4 / 7$ & 79.75 \\
2 & $2 / 3$ & 83.04 \\
3 & $3 / 5$ & 65.24 \\
4 & $1 / 3$ & 51.23 \\
\hline
\end{tabular}

Abbreviations: $\mathrm{P}=$ positive number of patients; Score=ACIS immunostaining media; TNM = classification of malignant tumours

position of the corresponding spot on the $2 \mathrm{D}$ gel (Figure $5 \mathrm{C}$ ), which was identified with accession number in UniProtKB/ SwissProt as Q5VV17.

\section{DISCUSSION}

Successful combinatorial antibodies have been obtained against various antigens for different diseases using phage display technology (Miller et al, 2005; Wolf et al, 2006; Flego et al, 2007). However, this is the first investigation, to our knowledge, that resulted in a specific scFv antibody associated with welldifferentiated thyroid carcinomas, mainly recognising early tumour stages. In addition, we have constructed an immune antibody library and scFvs were selected against antigens of the entire cell surface, which differentiates from most previously described selections of combinatorial antibodies that have been carried out using known and previously isolated antigens (Rauchenberger et al, 2003; Martinez-Torrecuadrada et al, 2005; Gorbenko et al, 2009). A completely cell-based procedure for antibody selection is an advantage for many membrane-associated proteins, as these proteins are often difficult to express and purify. Moreover, their complex structures and native conformations are maintained (Lipes et al, 2008).

Our immunohistochemistry results demonstrated that the selected scFv-C1 antibody was able to distinguish follicular variants of PTCs from simple benign hyperplasia. In addition, it helped identify smaller isolated T1 and T2 lesions, which may have a better response to therapy (Varandas et al, 2007). The identification of low-risk tumours is essential to the management of patients with papillary thyroid cancer (Cooper et al, 2009).

Mass spectrometry analysis of the spot immunostained with $s c F v-C 1$ led to the identification of an OTU domain-containing protein 1, alternatively named DUBA-7, which belongs to the deubiquitinating enzyme family (DUBs). DUBs are important enzymes that remove the covalently attached ubiquitin from proteins, thereby controlling substrate activity and/or abundance (Makarova et al, 2000). Because of the broad involvement of the ubiquitin-proteasome proteolysis in the regulation of protein turnover, this pathway may have a vital role in cancer development and progression (Yang, 2007). Several types of deubiquitinating enzymes have been associated with development and progression of cancers (Yang, 2007) and have been found to be upregulated in prostate cancer (Priolo et al, 2006), follicular lymphomas (Schwickart et al, 2010), colon and breast carcinomas (Popov et al, 2007). However, to the best of our knowledge, this is the first evidence that DUBA-7 has a role in thyroid carcinogenesis.

In summary, we constructed a human $\mathrm{scFv}$ fragment antibody library displayed in the fimalentous phage capsid, aiming to select ligands to the surface of thyroid cancer cells. We were able to identify a highly reactive antibody that distinguished benign follicular lesions from carcinomas, and that was also associated with lower-risk patients. Finally, we have demonstrated that the scFv-C1 antibody recognises a deubiquitinating enzyme, OTU domain-containing protein 1 , that is also overexpressed in other 

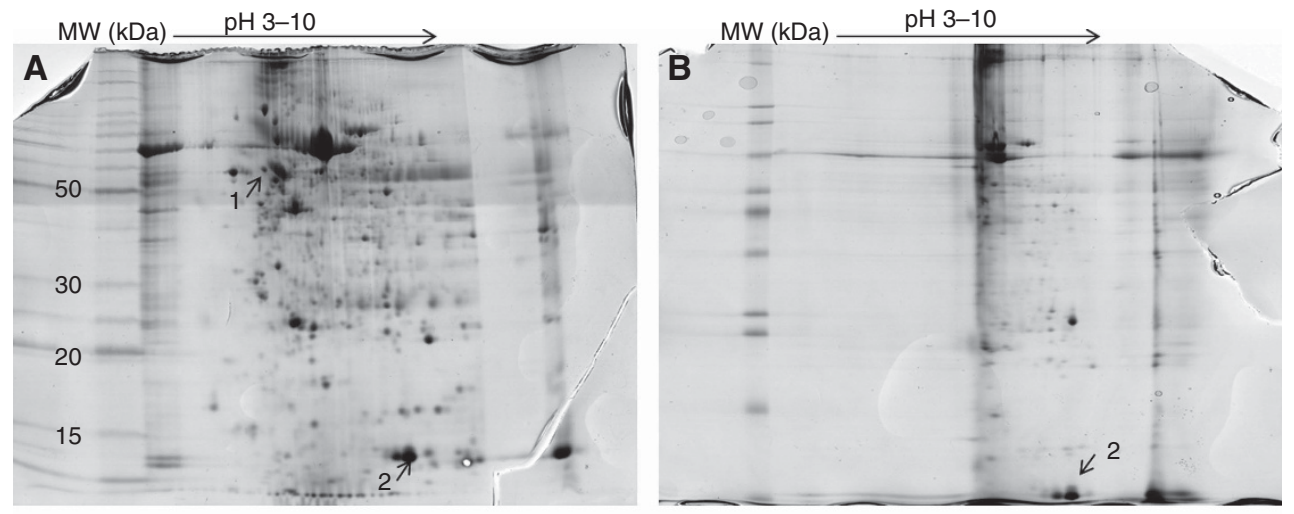

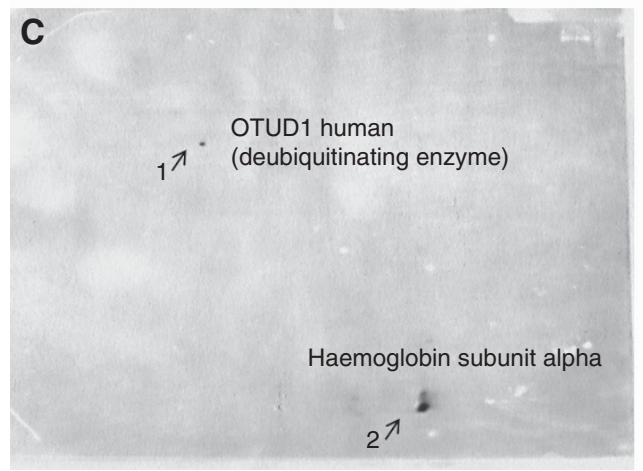

Papillary thyroid carcinoma tissue

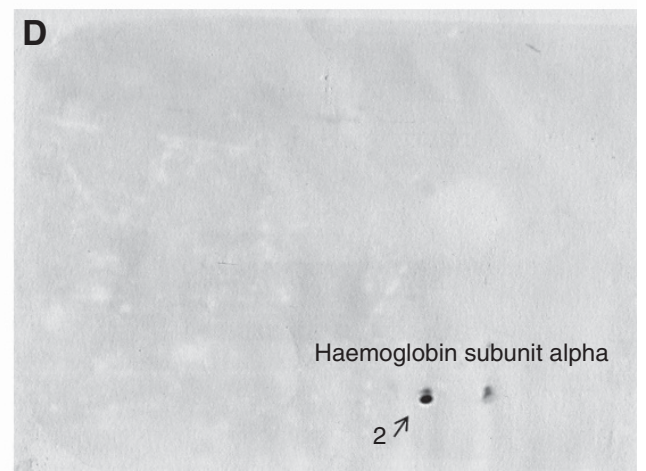

Goiter tissue

Figure 5. The two-dimensional gel electrophoresis of papillary thyroid carcinoma tissue (A) and goitre tissue (B). The sizes of the molecular weight markers (MW) are shown on the left side of panel A. The $\mathrm{pH}$ range was $3-10$. Western blot analysis of the scFv-C1 antibody in papillary thyroid carcinoma (C) and goitre (D); the deubiquitinating enzyme-OTUD1 appeared only in carcinoma.

cancers. This specific ligand may also be a potential therapeutic agent or drug carrier for future treatment strategies of thyroid cancer.

\section{ACKNOWLEDGEMENTS}

The present work was supported by the Brazilian funding agencies: Fundação de Amparo à Pesquisa do Estado de São Paulo (FAPESP), Fundação de Amparo à Pesquisa do Estado de Minas Gerais (FAPEMIG), Coordenação de Aperfeiçoamento de Pessoal de Nível Superior (CAPES) and Conselho Nacional de Desenvolvimento Científico e Tecnológico (CNPq). We thank Dr Jose Vassallo (A.C. Camargo) for performing IHC analysis, and the A. C. Camargo Hospital for providing tissue microarrays.

\section{REFERENCES}

Andris-Widhopf J, Rader C, Steinberger P, Fuller R, Barbas 3rd CF (2000) Methods for the generation of chicken monoclonal antibody fragments by phage display. J Immunol Methods 242: 159-181.

Andris-Widhopf J, Steinberger P, Fuller R, Rader C, Barbas 3rd CF (2011) Generation of human scFv antibody libraries: PCR amplification and assembly of light- and heavy-chain coding sequences. Cold Spring Harb Protoc 2011: 9.1-9.22.

Berger M, Shankar V, Vafai A (2002) Therapeutic applications of monoclonal antibodies. Am J Med Sci 324: 14-30.

Cooper DS, Doherty GM, Haugen BR, Kloos RT, Lee SL, Mandel SJ, Mazzaferri EL, McIver B, Pacini F, Schlumberger M, Sherman SI, Steward DL, Tuttle RM (2009) Revised American Thyroid Association management guidelines for patients with thyroid nodules and differentiated thyroid cancer. Thyroid 19: 1167-1214.

Cosimi AB, Colvin RB, Burton RC, Rubin RH, Goldstein G, Kung PC, Hansen WP, Delmonico FL, Russell PS (1981) Use of monoclonal antibodies to T-cell subsets for immunologic monitoring and treatment in recipients of renal allografts. N Engl J Med 305: 308-314.

Cunha LL, Morari EC, Guihen AC, Razolli D, Gerhard R, Nonogaki S, Soares FA, Vassallo J, Ward LS (2012a) Infiltration of a mixture of immune cells may be related to good prognosis in patients with differentiated thyroid carcinoma. Clin Endocrinol (Oxf) 77: 918-925.

Cunha LL, Morari EC, Nonogaki S, Soares FA, Vassallo J, Ward LS (2012b) Foxp3 expression is associated with aggressiveness in differentiated thyroid carcinomas. Clinics (Sao Paulo) 67: 483-488.

Davies L, Welch HG (2010) Thyroid cancer survival in the United States: observational data from 1973 to 2005. Arch Otolaryngol Head Neck Surg 136: $440-444$

Flego M, Ascione A, Zamboni S, Dupuis ML, Imperiale V, Cianfriglia M (2007) Generation of human scFvs antibodies recognizing a prion protein epitope expressed on the surface of human lymphoblastoid cells. $B M C$ Biotechnol 7: 38.

Giordano RJ, Cardo-Vila M, Lahdenranta J, Pasqualini R, Arap W (2001) Biopanning and rapid analysis of selective interactive ligands. Nat Med 7: 1249-1253.

Gorbenko O, Ovcharenko G, Klymenko T, Zhyvoloup O, Gaman N, Volkova D, Gout I, Filonenko V (2009) Generation of monoclonal antibody targeting fibroblast growth factor receptor 3. Hybridoma (Larchmt) 28: 295-300.

Guth S, Theune U, Aberle J, Galach A, Bamberger CM (2009) Very high prevalence of thyroid nodules detected by high frequency $(13 \mathrm{MHz})$ ultrasound examination. Eur J Clin Invest 39: 699-706.

Kilfoy BA, Zheng T, Holford TR, Han X, Ward MH, Sjodin A, Zhang Y, Bai Y, Zhu C, Guo GL, Rothman N (2009) International patterns and trends in thyroid cancer incidence, 1973-2002. Cancer Causes Control 20: $525-531$. 
Lipes BD, Chen YH, Ma H, Staats HF, Kenan DJ, Gunn MD (2008) An entirely cell-based system to generate single-chain antibodies against cell surface receptors. J Mol Biol 379: 261-272.

Makarova KS, Aravind L, Koonin EV (2000) A novel superfamily of predicted cysteine proteases from eukaryotes, viruses and Chlamydia pneumoniae. Trends Biochem Sci 25: 50-52.

Marks JD, Hoogenboom HR, Bonnert TP, McCafferty J, Griffiths AD, Winter G (1991) By-passing immunization. Human antibodies from V-gene libraries displayed on phage. J Mol Biol 222: 581-597.

Martinez-Torrecuadrada J, Cifuentes G, Lopez-Serra P, Saenz P, Martinez A, Casal JI (2005) Targeting the extracellular domain of fibroblast growth factor receptor 3 with human single-chain Fv antibodies inhibits bladder carcinoma cell line proliferation. Clin Cancer Res 11: 6280-6290.

Miller KD, Weaver-Feldhaus J, Gray SA, Siegel RW, Feldhaus MJ (2005) Production, purification, and characterization of human $\mathrm{scFv}$ antibodies expressed in Saccharomyces cerevisiae, Pichia pastoris, and Escherichia coli. Protein Expr Purif 42: 255-267.

Piana S, Frasoldati A, Ferrari M, Valcavi R, Froio E, Barbieri V, Pedroni C, Gardini G (2011) Is a five-category reporting scheme for thyroid fine needle aspiration cytology accurate? Experience of over 18,000 FNAs reported at the same institution during 1998-2007. Cytopathology 22: 164-173.

Popov N, Wanzel M, Madiredjo M, Zhang D, Beijersbergen R, Bernards R, Moll R, Elledge SJ, Eilers M (2007) The ubiquitin-specific protease USP28 is required for MYC stability. Nat Cell Biol 9: 765-774.

Priolo C, Tang D, Brahamandan M, Benassi B, Sicinska E, Ogino S, Farsetti A, Porrello A, Finn S, Zimmermann J, Febbo P, Loda M (2006) The isopeptidase USP2a protects human prostate cancer from apoptosis. Cancer Res 66: 8625-8632.

Rader C, Barbas 3rd CF (1997) Phage display of combinatorial antibody libraries. Curr Opin Biotechnol 8: 503-508.

Rauchenberger R, Borges E, Thomassen-Wolf E, Rom E, Adar R, Yaniv Y, Malka M, Chumakov I, Kotzer S, Resnitzky D, Knappik A, Reiffert S, Prassler J, Jury K, Waldherr D, Bauer S, Kretzschmar T, Yayon A, Rothe C (2003) Human combinatorial Fab library yielding specific and functional antibodies against the human fibroblast growth factor receptor 3. J Biol Chem 278: 38194-38205.

Retter I, Althaus HH, Munch R, Muller W (2005) VBASE2, an integrative V gene database. Nucleic Acids Res 33: D671-D674.
Roessler M, Rollinger W, Mantovani-Endl L, Hagmann ML, Palme S, Berndt P, Engel AM, Pfeffer M, Karl J, Bodenmuller H, Ruschoff J, Henkel T, Rohr G, Rossol S, Rosch W, Langen H, Zolg W, Tacke M (2006) Identification of PSME3 as a novel serum tumor marker for colorectal cancer by combining two-dimensional polyacrylamide gel electrophoresis with a strictly mass spectrometry-based approach for data analysis. Mol Cell Proteomics 5: 2092-2101.

Rosario PW, Ward LS, Carvalho GA, Graf H, Maciel RM, Maciel LM, Maia AL, Vaisman M (2013) Thyroid nodules and differentiated thyroid cancer: update on the Brazilian consensus. Arq Bras Endocrinol Metabol 57: $240-264$.

Schwickart M, Huang X, Lill JR, Liu J, Ferrando R, French DM, Maecker H, O'Rourke K, Bazan F, Eastham-Anderson J, Yue P, Dornan D, Huang DC, Dixit VM (2010) Deubiquitinase USP9X stabilizes MCL1 and promotes tumour cell survival. Nature 463: 103-107.

Seymour JF (2004) New treatment approaches to indolent non-Hodgkin's lymphoma. Semin Oncol 31: 27-32.

Varandas VM, Coelho SM, Soeiro AP, Coeli CM, Carvalho DP, Buescu A, Vaisman M (2007) [Clinical repercussion of the 6th edition TNM staging system classification on differentiated thyroid carcinoma]. Arq Bras Endocrinol Metabol 51: 825-831.

Wilm M, Shevchenko A, Houthaeve T, Breit S, Schweigerer L, Fotsis T, Mann M (1996) Femtomole sequencing of proteins from polyacrylamide gels by nano-electrospray mass spectrometry. Nature 379: 466-469.

Wolf P, Gierschner D, Buhler P, Wetterauer U, Elsasser-Beile U (2006) A recombinant PSMA-specific single-chain immunotoxin has potent and selective toxicity against prostate cancer cells. Cancer Immunol Immunother 55: 1367-1373.

Yang JM (2007) Emerging roles of deubiquitinating enzymes in human cancer. Acta Pharmacol Sin 28: 1325-1330.

This work is published under the standard license to publish agreement. After 12 months the work will become freely available and the license terms will switch to a Creative Commons AttributionNonCommercial-Share Alike 3.0 Unported License.

Supplementary Information accompanies this paper on British Journal of Cancer website (http://www.nature.com/bjc) 